\title{
Education as Reconciliation: Resorting Inuit Nunangat
}

\author{
Jay McKechnie ${ }^{1, *}$ \\ ${ }^{1}$ PO Box \#479, Pond Inlet, NU, Canada \\ *Correspondence: PO Box \#479, Pond Inlet, NU, Canada. E-mail: jmckechnie@teachers.ntanu.ca
}

Received: October 12, 2014

Accepted: January 12, $2015 \quad$ Online Published: March 8, 2015

doi:10.5430/jct.v4n1p56

URL: http://dx.doi.org/10.5430/jct.v4n1p56

\begin{abstract}
Education is stated as the number one priority of the Government of Nunavut's Sivumiut Abluqta mandate. The Nunavut education system is seen by many as failing to provide Inuit with the promise of supporting Inuit economic and social well-being. Today in Nunavut, there is a growing awareness of the effects of past colonialist polices and the need for individual and group healing. However, within the current education reforms, there is little discourse that reflects this colonialist history and how it continues to shape education in Nunavut.

This paper seeks to answer the following questions: How did the transition from an autonomous lifestyle on the land, to a dependent lifestyle in communities, affect Inuit society? How are the intergenerational affects of this transition manifested in the classrooms of Nunavut? How can the education system facilitate a public discourse that supports healing and reconciliation?

As a high school social studies teacher in Nunavut, I am primarily interested in addressing the role of Qallunaat (non-Inuit) teachers working in Nunavut. As part of the effort across Canada to find meaningful ways of reconciling the relationship between Aboriginal and non-Aboriginal Canadians, I see myself as an educator as having an important role in this process of reconciliation.

I will discuss the complex interplay of colonialist policies, intergenerational trauma, attachment, and change through the lens of Paulo Freire's Pedagogy of the Oppressed. I will argue that understanding how intergenerational trauma continues to shape education in Nunavut is crucial in creating a shared narrative, that can ultimately lead to reconciliation by bringing individuals together in partnerships, to undertake the healing process and social reform.
\end{abstract}

Keywords: Nunavut; education; intergenerational trauma; reconciliation

\section{Introduction}

The Third Government of Nunavut Cabinet has promised to reform the education system for Nunavummiut as outlined in the Sivumiut Abluqta mandate. The complex interplay of historical trauma resulting from colonialist policies, and the current neo-liberal based education reforms, makes Nunavut an exciting site for engaging the topic of Aboriginal control of education.

Canadian assimilation policies in the early part of the twentieth century were aimed at destroying Aboriginal culture. In Nunavut, the most destructive episodes of these policies were the relocation of Inuit into permanent settlements, followed by the residential school experience. The justification of the relocation of Inuit during this time period was due to many economic, political, and cultural factors. How did the transition from an autonomous lifestyle on the land, to a dependent lifestyle in communities, affect Inuit society in Nunavut? How are the intergenerational affects of this transition manifested in the classrooms of Nunavut? How can the education system facilitate a public discourse that supports healing and reconciliation?

The reconciliation process demands a critical engagement with education in Nunavut to develop a shared narrative between Inuit and Qallunaat (non-Inuit). This shared narrative involves a comprehensive understanding of relocation and residential schools, intergenerational trauma, contemporary education in Nunavut, attachment theory, and the change process. In section one, I will begin with the history of relocation and colonialist policies in Nunavut, beginning in the 1930's, which includes residential schools. The impact of residential school on Inuit culture and society will provide a context for engaging the complex issues of intergenerational trauma and attachment theory in 
section two. From this historical perspective, I will discuss the contemporary issues facing education in Nunavut in section three. Finally, section four will provide a critical examination of the change process.

I will discuss the complex interplay of these histories and ideas through the lens of Paulo Freire's Pedagogy of the Oppressed. I will argue that a shared narrative requires an understanding of how intergenerational trauma continues to shape education in Nunavut. A shared narrative creates a platform for communication as a means of fostering a sense of solidarity to bring about meaningful change. The essence of reconciliation attempts to develop an understanding of the past by bringing individuals together in partnerships, in order to undertake the healing process and social reform.

\section{Section 1: Relocations and Residential School - Historical Context}

\subsection{Relocations: Inuit Nunangat}

The expression Inuit Nunangat, translates as 'the peoples land'. This term is used by Inuit to refer to their isolated part of the world. As Hugh Brody explains, this expression goes far beyond mere geographical significance, but in fact represents an ideal. The very idea of land permeates Inuit culture. The land is the place of the hunt, family, language, and culture; it is simply where one belongs. "To change or abandon such a place, according to this worldview, would be dangerous and foolish" (Brody, 2000, p. 15). As Brian Osborne points out, "the central premise of the geography of identity is human attachment to particular spaces" (Osborne, 2001, p. 2). The relocation of Inuit in the 1950s had a tremendous impact on Inuit culture, as it took Inuit off the land and away from their identity.

During the 1940's, particularly following the Second World War, great changes took place in the Eastern Arctic that influenced every aspect of Inuit culture and society. Frank Tester and Peter Kulchyski's important work on the relocation of Inuit in the Eastern Arctic entitled, Tammarniit (Mistakes) offers an in-depth analysis of the government polices of assimilation and the various reasons for the relocation of Inuit. Beginning in the 1930s, and lasting for the next forty years, relocation was used to deal with various issues of dependency and welfare as a result of contact with southern culture. Inuit were relocated to the south for tuberculosis treatment, to army bases for employment, and to remote parts of the Arctic by the Hudson Bay Company to take advantage of the fox trade. During the 1940s and 1950s, children were moved to attend residential school, and later, Inuit were relocated to establish Canadian sovereignty in the High Arctic (Tester \& Kulchyski, 1994). These decisions were based on the assumption that assimilation was for the benefit of Inuit (Henderson, 2007).

Due to increasing contact with Qallunaat, an autonomous lifestyle on the land was becoming increasingly difficult to maintain. The ability to rely on trapping as a source of income became extremely difficult with the collapse in fox fur prices in the late 1940s. Government dependency now became the harsh reality for Inuit as the economic conditions became so bad in the Eastern Arctic that relying on some form of social assistance became a necessity (Tester \& Kulchyski, 1994). Traditional cultural practices now shifted in order to compensate for these new economic realties. One such shift can be illustrated trough traditional adoption practices. Prior to contact, traditional adoption practices often meant "children would often move extensively within the extended family unit. With the advent of family allowance, children became a source of income in a situation where income was very scarce" (Tester \& Kulchyski, 1994, p. 72). This meant that children had to be attending school in order for the family to receive their family allowance.

Ironically, and as a testament to Inuit resiliency, the residential school system was in fact producing radical ideologies in young Inuit. The argument for Inuit self-government, leading to the signing of the Nunavut Land Claims Agreement in 1993, was a result of young Inuit students subverting the assimilation polices into forms of resistance. The efforts of these educated Inuit are the embodiment of what Paulo Freire refers to as "[t]he pedagogy of the oppressed, which it is the pedagogy of people engaged in the fight for their own liberation" (Freire, 1970, p. 53). However, intergenerational trauma, and issues of dependency resulting from these historical events, remains a large obstacle to overcome in order to realize the potential of Nunavut.

\subsection{The Impact of Residential School}

The destructive nature of residential school resulted from separating Aboriginal peoples from their cultural identity. Residential school can be summed up as a "process of dispossession: of separating people from their means of sustenance, which, in most cases and for most cultures, is the land" (Tester \& Kulchyski, 1994, p. 6). Aboriginal identity is a tightly interwoven web of land, history, and language.

Residential school was a systematic attempt by the Canadian government to destroy Aboriginal culture in order to 
assimilate Aboriginal peoples into mainstream society. The aim of residential school was to convert Aboriginal peoples to Christianity, teach them English or French, and force them to abandon their cultural heritage. The schools were funded by the federal government and generally operated by various religious institutions (Barnes et al., 2007). Education was not the main objective of this system, and even though some Aboriginal peoples report a positive experience at residential school, the vast majority describe traumatic experiences due to neglect, abuse, and cultural and family dislocation (Barnes et al., 2007). The poor living conditions, and low standards of physical and mental health at the schools, has had a significant adverse impact on Aboriginal peoples' educational progress and psychological development throughout Canada (Barnes et al., 2007).

For Inuit, the tensions created by the schools, and the experience of relocation in general, has had grave intergenerational impacts. Intergenerational trauma is often experienced through various forms of abuse, neglect, poverty, drug and alcohol abuse, and suicide. In Nunavut, these intergenerational issues have resulted in "high unemployment and a low median income, high addiction and suicide rates, overcrowded housing, and lower health status than any other province or territory" (Berger, 2007, p. 2). This intergenerational cycle gains momentum as it moves further away from the original source of suffering and begins to define the norms of relationships within a community, if not interrupted and left untreated.

\section{Section 2: Intergenerational Trauma and Schooling}

\subsection{The Language of Trauma}

In order to break the cycle of intergenerational trauma, communities require the appropriate language to speak of these specific experiences. This is significant when one considers the impact residential school had on Aboriginal language. Marie Battiste explains, "Aboriginal languages provide a direct and powerful means of understanding the legacy of tribal knowledge" (Battiste, 1998, p. 18). The language of trauma tends to resonate deeply in Aboriginal communities as it provides a way of expressing the collective and individual pain of the community. The language of trauma does however belong to the dominant culture. The necessity of adopting an element of the dominant culture in order to resist and reconcile the larger attempt of assimilation is an interesting irony. The adoption of this specific discourse allows for the recognition and legitimacy within the dominant culture to aid in the process of healing and reconciliation (Styvendale, 2008).

I will use the word trauma to speak of the intergenerational issues that Inuit face in Nunavut. In order to speak about trauma in a meaningful manner, I must include what is uncomfortable to write. As Calliou (2001) explains, a day at residential school involved:

A school day included sexual assault, unwanted genital examination, forced oral-genital contact, public strip searches, starvation, substandard nutrition, beatings, burning, belittling's, humiliations (about appearance, language, accent, bodily functions), linguistic degradation and other chargeable criminal offences. (p. 204)

The overall impact of trauma is complicated by many different factors. In terms of abuse or neglect experience during childhood, "the overall impact depends on developmental issues such as: the age at which the abuse began; the nature, severity and duration of the abuse; the relationship to the perpetrator; and the nature of the child's attachment to her or her parents/parental figure" (Haskell \& Randall, 2009, p. 59). As a result of being exposed to abuse, or in general the poor living conditions at the residential schools, students were likely to experience "disrupted or delayed psychological development" (Barnes et al., 2007, p. 28). These individuals were not only at risk to develop these disturbances while attending residential school, but also at risk of experiencing these disturbances later on in life. These issues manifest themselves in contexts that are far removed from the residential school experience. This can lead to residual trauma on the immediate family of those who attended residential school. Furthermore, as the primary function of school is to develop the cognitive abilities of students, Inuit did not benefit from this formal education experience. This is especially pronounced if the conditions at the school led to Inuit students leaving school early, or if they made limited or inadequate progress. When these poor educational outcomes are combined with traumatic experiences, these variables contribute to a student's inability to succeed in education at a later time. The long-term effects of this lack of educational achievement translate into issues of employment, reduced income, and poor health in adult life (Barnes et al., 2007). As noted above, some former residential school students have gone on to become today's leaders in public office, education, and business. This presents a challenge in navigating the sophistication of historical trauma and the way communities deal with this trauma as a shared narrative.

\subsection{Defining Historical Trauma}

Historical trauma may be best defined as the "cumulative emotional and psychological wounding, over the lifespan 
and across generations, emanating from massive group trauma experiences" (Denham, 2008, p. 396). Ruth Leys offers a keen insight into how this type of trauma can replay itself intergenerationally as "massive trauma precludes all representation because the ordinary mechanisms of consciousness and memory are temporarily destroyed...what returns to haunt the victim ....is not only the reality of the violent event but also the reality of the way that its violence has not yet been known" (Styvendale, 2008, p. 218). The way this trauma is often transmitted from one generation to the next is through the silence of untreated trauma (Denham, 2008). As Dumont et al, make clear, "Suppression of emotion comes at a cost, however, as it is associated with feeling of loss of control and depression. It reduces cognitive resources for ongoing and upcoming activities because it requires continuous monitoring during the emotion episode" (Dumont et al., p. 103). To speak out loud is to validate and confront ones experience and emotions. In silence, the emotions remain unresolved.

The problem of speaking about trauma is that it tends to be fixed as a single event in time. If individuals are unable to understand and comprehend the events as they are taking place, this "causes its reiterative -and performative-reenactment in the present" (Styvendale, 2008, p. 218). Bruce Bradfield explains that this can create problems in one's development of relationships as the individuals create potentially dangerous methods of defense to protect themselves (Bradfield, 2011). Ultimately, instead of dealing with the trauma, it gets reflected in one's relationship, which then creates more trauma rather than dealing with the original cause. This lack of a coherent narrative will ultimately affect the patterns of relationships this individual encounters in life (Bradfield, 2011).

These issues are most pronounced in individuals who experienced criminal victimization trauma in adolescence. This can result in the lower outcomes as discussed above, as well as a higher chance of being exposed to victimization later in life (Barnes et al., 2007). There is a need to identify the mechanisms that promote intergenerational trauma to occur. Traumatic events may alter cognitive processes, particularly in dealing with stressors, and can affect one's cognitive performance when under stress (Bombay et al., 2009).

Bradfield argues that it is important to understand the specific characteristics of trauma experienced at a young age, as "[c]hildhood trauma is developmentally significant in terms of its impact on the particular quality of attachment relationships that develop between mother and child in terms of the child's consequent capacity for relationships with others" (Bradfield, 2011, p. 534). The cumulative, collective, intergenerational, and intersubjective nature of the trauma Inuit have experienced (Styvendale, 2008) requires an understanding of specific events such as residential school, and how it affects education in Nunavut today.

The complexity of these intergenerational issues must be a part of the educational discourse in Nunavut. Education presents the possibility for healing. But a teacher entering a Nunavut classroom unaware of this historical trauma faces a difficult learning curve and this can be emotionally taxing for both student and teacher. Unless teachers are trained in this history, and provided with the culturally relevant (Aylward, 2009) and theoretical tools to constructively engage these issues, they are simply not prepared for the difficulties they will encounter.

\subsection{Attachment Theory}

The importance of attachment theory is in understanding that attachment is meant to protect against stress. Having a strong sense of attachment provides a sense of security against emotional stress, which is important during the early stages of development. As Haskell and Randalll point out, "attachment not only helps with security in childhood, but also plays a key role in well-being and mental health throughout a persons lifespan" (Haskell \& Randall, 2009, p. 63). This is an important theory for teachers, especially when working in a context where there has been a disruption in attachment in the lives of their students. Attachment theory is based on the work of John Bowlby. In short, Bowlby identified three forms of attachment: the securely attached, avoidantly attached, and the ambivalently attached (Karen, 1994).

The most basic understanding of attachment is the biological need for attachment between an infant and her mother, or primary caregiver. This attachment is crucial for neurobiological development. This early attachment is called attunement that facilitates early brain development. The ideal attachment for this to occur is secure attachment and consists five basic elements: 1) Collaboration - attuned communication between infant and mother is responsible for the early development of a sense of self. 2) Reflective dialogue - shared internal dialogue between infant and mother. 3) Repair - during time where attunement is disrupted as a natural consequence of life, the repair of this disruption is essential in re-establishing the connection between infant and mother. A prolonged disconnection can negatively affect the child's sense of self. In a sense, the infant looses its orientation in the world. 4) Coherent narrative-secure attachment allows for the sequencing, and integration of experiences. And 5) Emotional communications-this reduces, regulates and helps soothe negative emotional states of the infant (Haskell \& Randall, 2009). To ensure secure attachment in children, they need a consistent relationship with their mother. The most important feature of 
emotional communication is that the mother and infant share these experiences together, not as a mirrored experience, but within the self (Haskell \& Randall, 2009).

\subsection{The Effect of Attachment on Learning}

A child's "later ability to think clearly and solve problems in a calm, non-impulsive manner stems from their experiences in the first five to seven years of life." (Haskell \& Randall, 2009, p. 65) Residential school disrupted these attachments for Inuit children, and when combined with the abuse, neglect, and deprivation experienced at residential school, these "difficulties with attachment reverberate throughout a traumatized person's entire life, and affect her or his relationship with self and with others (Haskell \& Randall, 2009, p. 65). The disruption of attachment manifests itself in violence and neglect, as former residential school students become parents who lack parenting knowledge and skills. This has a profound impact on the whole community as generation after generation experience neglect as a result of poor parenting. The relationship between this lack of attachment within the early stages of development is particularly destructive in the educational outcomes of a child. The primary function of attachment is to provide the child with a sense of attachment while she is developing (Haskell \& Randall, 2009). This sense of insecurity interferes with learning, as learning requires a certain amount of risk taking and personal motivation to succeed. If a student lacks this sense of security, then school can be a difficult place to navigate. Piaget believed that "exploratory" behaviour is an essential part of our innate qualities of human behaviour (Karen, 1994). The level of attachment will determine the amount confidence a child has in exploring the world in unfamiliar and challenging circumstances. By understanding the basic tenants of attachment theory, teachers can create a learning environment that is conducive to facilitating a sense of security by limiting the amount of stressors students encounter. This connects to the Inuit societal value inuuqatigiitsiarniq, which is the concept of respecting others, relationships and caring for people (Government of Nunavut, 2013).

For me personally, this concept of relationships has become more apparent the longer I remain in the community. Returning to the classroom year-after-year allows me to develop secure attachments with students. The common refrain by students at the start of the school year of "you're back" demonstrates the sincere surprise that you want to be here. In my social studies classes, we often discuss teacher turnover as being one of the major stressors students experience. Having to continuously get to know new teachers lends itself to a lack of consistency in the educational careers of students. A lack of trust is one consequence of this reality in Nunavut. With time, student and teacher get to know each other, and with this time, secure attachments, trust, and cultural awareness develops.

\subsection{Attachment and Teaching}

As noted above, secure attachments take time. In general however, attachment theory is well suited to the realities of Nunavut classrooms. Knowing that there is someone in the world that cares for you can create a sense of resiliency. This is a significant factor in a child's ability to believe in herself and overcome adversity in life (Karen, 1994). The school can be a space to provide this function, however; it lacks a certain level of capacity to provide long lasting attachment due to the temporal nature of the student-teacher relationship. The student-teacher relationship can help foster a sense of security, but it is not enough to promote this sense of well-being. This sense of well-being must ultimately become an intrinsic quality within the student. But if the student comes from a traumatic background, then it is not appropriate to expect the student to develop this sense of well-being on her own. Creating a safe and secure classroom is something that every teacher can do to help develop a sense of well-being in her students. Teachers who are sensitive to the anxieties of the child are in a position to model healthy relationships. As Robert Karen explains, "The child's understanding of relationships can only be from the relationship's he's experienced" (Karen, 1994, p. 195).

Children with secure attachment histories generally preform better at ego resiliency, self esteem, independence, and the ability to enjoy themselves as well as responding positively towards other children than children from ambivalent backgrounds (Karen, 1994). Children who lack this secure attachment histories can create challenging scenarios in the classroom through behaviour and poor relationships skills with the teacher and fellow students. Teachers can enact attachment theory by creating a positive classroom community through containment and attunement. If a teacher can contain behaviour within reasonable and well-defined limits, and be consistent, this can help create a supportive environment for students by establish boundaries that are predicable. With attunement, the teacher tunes into the child through a loving, caring and understanding approach to where the child is coming from (Friere, 1970). If a teacher can be consistent in containment, which involves natural and logical consequences, a relationship of trust can develop (Karen, 1994). "A child's capacity to handle psychological and physiological stress is completely dependent on the relationship with her or his parent" (Haskell \& Randall, 2009, p. 65). In the absence of this support a child will be unable to learn how to regulate stress in her life. This inability to regulate emotions is at the very core 
of trauma responses (Haskell \& Randall, 2009) and is something that teachers who are working in these situations, need to be aware of. Students who live with intergenerational trauma develop mechanisms to hide hurtful and shameful feelings that are unmanageable to deal with by building up defenses. As Haskell and Randall explain, "The psychological outcomes of an inability to both regulate emotions .... and feel secure in relationships results in the need to develop adaptations in order to survive" (Haskell \& Randall, 2009, p. 60). Helping a student feel secure and providing a sense of self-worth can help combat the "unexamined and hateful self-concepts first incorporated at a young age" (Karen, 1994, p. 206) that can interfere with learning. For Qallunaat educators, helping students develop a sense of identity that is culturally relevant requires systematic support and personal reflection on ones own personal epistemologies (McKechnie, 2014). As for the entire educational community, this demands confronting memory as the first step towards healing. As Sherilyn Calliou notes, "memory comes before knowledge" (Calliou, 2001, p.199). The education system must lead this effort of facilitating the task of remembering in order to heal. But the current focus of the Government of Nunavut mandate in regards to education is to improve literacy. The GN sees education as the means of obtaining jobs within the ever-increasing resource development economy with the objective of decreasing government dependency in Nunavut (Government of Nunavut, Building Nunavut Together (Sivumut Abluqta), 2014). This of course is a noble task in respect to the history of colonialism affects on Inuit autonomy. But I would argue that this does little to confront the more sophisticated issues of trauma that persist in Nunavut communities.

\section{Section 3: The Role of Education in Reconciliation}

\subsection{Education in Nunavut Today}

The Inuit societal value ikajuqtigiinniq can be understood as the concept working together for a common cause (Government of Nunavut, 2013). Unfortunately, the continued legacy of colonialism often interferes with the ability to fully embody this ideal through lateral violence. Lateral violence is a destructive, divisive, and insidious force that impacts the whole community. The Legacy of Hope final report (2004) on violence and victimization defines lateral violence as "an internalized feeling of anger and rage that develops in a person as a result of being constantly put down. It is also manifests itself in [communities] through family feuds, gossip and organizational infighting. It is responsible for dividing ...communities into factions, thereby preventing...[them] from becoming a more strong and unified people" (Legacy of Hope: An Agenda for Change, 2004, p.3-2 \& 3-3). One can see lateral violence as an attempt to resist and deal with assimilation, albeit in an unhealthy, destructive manner, that ultimately affects capacity building in the community. As Friesen and Friesen (2002) explain, "[w]hen the residential school system was finally shut down, it did not signal an end to the ongoing struggle for cultural recognition and meaningful education for [Aboriginal] people. They still faced the perpetual challenge of not yielding to the subtle influence of assimilation" (p. 114). In this sense, it is easy to see why there is resistance towards schooling. Schooling remains a western institution, where Inuit values are present, but the majority of teachers and administrators are Qallunaat. There also remains a "deeply embedded nature of colonial hegemony in institutionalized practices, knowledge, language, and thought" (Schissel \& Wotherspoon, 2003, p. 27). Clearly, this historical residue needs to be addressed through a mutual understanding of the colonialist narrative. As Osborne states, "[c]itizens need to know what their ancestors have done and what their state is capable of ... if they are to deal adequately with the issues that face them" (Osborne, 2003, p. 604). Freire (1970) argues for the need of intervention in order to allow the oppressed to develop a critical pedagogy to liberate themselves from oppression. This requires dialogue through partnerships. The historical oppressor (Qallunaat) must be intimately involved in this struggle towards liberation.

There is a growing sentiment of dissatisfaction with the education system in local discourse throughout Nunavut (CBC, 25/11/12. Dawson, 7/3/13. Dawson, 11/3/13). If students in Nunavut are dropping out of school early, or graduating high school without the necessary skills and knowledge that will allow them to be autonomous, then education is actually serving to continue the oppression of Inuit through the continuation of dependency on government support, as addressed in the Sivumut Abluqta mandate. The promise of education is that it can create systematic change for the benefit of Inuit society and culture. It is widely acknowledged that the success of any school system requires the support and encouragement of all stakeholders. This requires parents and other community members to participate in the educational discourse. The community needs to directly influence the operation of the school, as the school is meant to serve the specific needs and values of the community it serves (Schissel and Wotherspoon, 2003). The structures are in place to make this happen, but the tensions that surround education in the north remains. The time for Nunavut to engage in critical reflection in order to expose the "oppressed consciousness and the oppressor consciousness" (Freire, 1970, p. 55) is the only means of moving forward in unity. 
Freire argues this requires "critical thinking by means of which people discover each other to be "in a situation"” (Freire, 1970, p. 109). By definition, Nunavut is a territory under Inuit self-government. So in a sense, the historically ingrained power imbalances are fundamentally challenged by this reality. But one of the most insidious elements of the colonized consciousness is a feeling of "self-depreciation" which results from the internalization of the opinion of the dominant culture's opinion of the colonized (Freire, 1970). So, how can a state that is self-governed by Inuit maintain hegemonic hierarchies of power that continue to uphold dominant hegemonies?

The creation of the Nunavut Education Act in 2006 was the result of community consultations and contains the community's expectations for education (Berger, 2007). The control of education at the community level is understood to be of the utmost importance if education is to fulfill its promise in Nunavut (Berger, 2007, McGregor, 2010). However, the assimilation of Inuit continues because the schools remain southern models, and are predominately staffed by Qallunaat, resulting in curriculum, resources, and teaching methods being saturated with Qallunaat culture and social norms (Berger, 2007). In 2009 only 37\% of Nunavut teachers were Inuit (White, 2009). And this contuse assimilation of Inuit is even more apparent if education is seen only as a means of acquiring employment (Government of Nunavut, Sivumut Abluqta, 2014).

\subsection{Ikajuqtigiinniq: Working Together for a Common Cause}

A solution to these broad and complicated issues in Nunavut must be based in culturally relevant pedagogies (Aylward, 2009) under the direction of Inuit, including partnerships with Qallunaat. However, since the creation of Nunavut in 1999, there is a growing division between Inuit and Qallunaat in Nunavut communities (Henderson, 2007). As Charles Taylor notes, "[f]ragmentation arises when people come to see themselves more and more atomically, otherwise put, as less and less bound to their fellow citizens in common projects and alliances" (Taylor, 1991, p. 112). If Nunavummiut are committed to improving the education system in Nunavut, Inuit and Qallunaat must find a common ground of mutual understanding to foster dialogue (McKechnie, 2014).

For example, the Canadian Red Cross offers a community workshop entitled, Walking the Prevention Circle. The program description on their website reads as follows,

Walking the Prevention Circle acknowledges the history, challenges and potential of Aboriginal individuals and communities as it explores issues relating to abuse, neglect and interpersonal violence. Designed for adults, this workshop empowers participants to name and reclaim the past, and begin the transition from the cycle of violence to the circle of healing, a journey that begins with awareness and moves toward prevention (redcross.ca).

The target audience for this workshop are Aboriginal people or people who work with First Nations. A program such as this, adapted to the specifics of Inuit culture and history, is an example of what is needed to create a shared narrative in Nunavut. Connecting both Inuit and Qallunaat within the relationship of colonialism is a means of accepting and understanding the past as the common ground that exist as our shared history, and then using this mutual understanding to move forward in the reconciliation process. As St. Denis succinctly points out, "Colonization and racialization are ... what tie Aboriginal people to non-Aboriginal" (St. Denis, 2007, p. 1087). The common experience of colonization can act as a point of unity within education, to work towards an understanding of the past and to create meaningful change in the future. Challenging the status quo as a unified front can become, what Taylor calls "[t]he politics of resistance...[that can become]...the politics of democratic will-formation" (Taylor, 1991, p. 118). But people are generally unwilling to become politically involved if they do not identify with their political community (Taylor, 1991). Education plays an important role in this cause, by promoting political empowerment and by bringing people together for a common purpose. This begins with a commitment to critical reflection and dialogue as the first step towards the empowerment of Inuit (Freire, 1970).

During the 2013-14 academic year, the Department of Education provided a two-day in-service to all educators in Nunavut on the newly approved social studies curriculum on residential school (Government of Nunavut, Government of Northwest Territories, Legacy of Hope Foundation, 2012). This was an excellent opportunity for all members of the education community to learn together about this colonial history. However, it was noted by many of my colleagues that a two-day in-service only scratched the surface of a complicated, and highly relevant, issue. Many educators, Inuit and non-Inuit, were both grateful and frustrated to learn about this topic and its impacts in which they had little knowledge prior to the in-service. I think this clearly speaks to a need, and a strong desire, to learn more above these issues in order to better serve our students and communities.

In-service opportunities such as these two examples offer what Tester and Kulchyski (1994) speak about when they discuss the importance of totalization as a way to describe the very essence of colonialism. Totlalization is a way of producing strong emotions in order to understand through empathy. The authors explain, "Totalization is a process of 
consciousness, a way in which consciousness apprehends the world" (Tester \& Kulchyski, 1994, p.5). This offers a way for both insider and outsider to create a shared narrative of the suffering endured at residential school. A partnership in developing the awareness of historical sensitivities will aid in the process of healing and reconciliation. Part of this totalization requires a common language in which to speak of these specific experiences. As Bruce Bradfield notes, "the unspeakable and inarticulable quality of trauma" (Bradfield, 2011, p. 532) is part of the problem when dealing with these issues, as it is naturally difficult to talk about. The need for praxis of critical and liberating dialogue through reflection can lead to meaningful action (Freire, 1970). As Freire explains, a "deepened consciousness of their situation leads people to apprehend that situation as an historical reality susceptible of transformation" (Freire, 1970, p. 85). The refusal to accept the historically imbedded power relationship is to commit to a culture of dependency and a sense of hopelessness. The need for dialogue is necessary in order to 'name' the world, to disrupt the silences, in order to change it (Freire, 1970). By creating a pedagogy of discourse where Inuit and Qallunaat work with each other in creating true solidarity through acts of love is essential to this praxis (Freire, 1970). How can this shared narrative be translated into systematic change?

\section{Section 4: Change as Process}

\subsection{Systematic Change Must Involve Solidarity}

The reason reform often fails is not a result of a lack of innovation, "but the enormous overload of fragmented, uncoordinated, and ephemeral attempts at change" (Fullan \& Miles, 1992, p. 745). Change is a process that invites problems to be the core of communication and is helpful in understanding how educational reform can be successful. This must involve all stakeholders in education by developing a shared narrative that articulates the historically situated issues that are responsible for the deeply imbedded hegemony in Nunavut. Understanding that education reform is both a political and an educational process is key (Fullan \& Miles, 1992). As Fullan and Miles explain, "changes in structure must go hand in hand with culture and in the individual and collective capacity to work through new structures" (Fullan \& Miles, 1992, p. 748). The failure to institutionalize change into the normal structures and practices throughout the education system will lead to their disappearance (Fullan \& Miles, 1992). As Harvey McCue is clear to point out, the intent is not enough. There is a need for system-level reforms to create lasting and meaningful change. Initiatives and programs at the school level can create change, but they often fall short of the wider transformations as they rely heavily on individual commitment. Just as teachers and administrators are not permanent fixtures in schools, the ruling government of the day is unstable and vulnerable to elections. Therefore, there is a need for a consistent reference point. McCue explains, "The net effect of nibbling around the edges is temporary" as the transition between personnel often results in "innovations [withering] on the vine" (Lewington, 2013, p. 39). This leads to a sense of cynicism about change as "a result of a loss of faith in change agents or a history of unsuccessful change attempts" (Walker et al., 2007, p. 765). Therefore, the change effort must be based on sound research, including educational experience, knowledge of colonialism, intergenerational trauma, attachment, and change theory.

Reform in itself is a systematic process and requires both knowledge of the change process itself, and examples of how success can result in "new structures, procedures, and school cultures that press for continuous improvement" (Fullan \& Miles, 1992, p. 748).

\subsection{Seven Themes for Change}

Fullan and Miles (1992) offer seven basic themes that need to be contemplated in relation to each other in order for systematic reform to be successful. This involves:

1. Change is learning (creating personal meaning through a learning process).

2. Change is a journey (it is not static and so it needs to be seen as a process that is fluid).

3. Problematics are necessary (problems are a natural part of the change process and lead to effective responses by developing creative solutions. This echoes Freire's problem posing method of education).

4. Change requires resources (training, additional resources/ space, etc.).

5. Change requires leadership (communication is key between all stakeholders involved in the change process which ensures solidarity and personal commitment).

6. Change is systematic (development and interrelationships of main components [curriculum, teaches, administrators, etc.], and a focus on structure, policy, regulations and culture). 
7. Large-scale change must be implemented locally (implementation by everyday actions of the school community).

Through developing a consciousness of these seven principles, and using them as a point of solidarity, is key to change. The change process is fundamentally a learning process that must be viewed as something that requires time and commitment. This in turn requires innovative, inspired, and committed leadership. As Freire notes, "[o]nly the leaders' own involvement in reality, within an historical situation, [leads] them to criticize this situation and to wish to change it" (Freire, 1970, p. 67). The narrative character of education (Freire, 1970) needs to be translated throughout the entire system. This narrative partnership throughout the education system is required as "[t]he behaviors of organizational leaders directly influence actions in the work environment that enable change" (Gilley et al., 2009, p. 38). In essence, the reformation of education as a means of liberation requires acts of cognition, and not transferals of information within the structures of authority (Freire, 1970). A sense of solidarity through dialogue leads to successful change. But this requires the difficult task of inviting and engaging conflict and demands a shared understanding amongst all stakeholders in education. This is because successful change requires making the change process explicit within the minds and actions of individuals, but also contributing to the knowledge of change as part of the entire social context (Fullan \& Miles, 1992). In sum, the pursuit of liberation must be a drive towards reconciliation as a unified praxis, where all Nunavummiut are committed to action and reflection in order to transform the education system (Friere, 1970).

\subsection{Problem Posing Method of Education and the Change Process}

Freire's problem posing education involves a "constant unveiling of reality" (Freire, 1970, p. 81). In other words, inviting problems into the change process leads to creative solutions. In order to arrive at this point, conflict and deliberation must be openly accepted as part of the change process. The problem-posing approach to education allows people to "develop their power to perceive critically the way they exist in the world with which and in which they find themselves; they come to see the world not as a static reality, but as a reality in process, in transformation" (Freire, 1970, p. 83). For this theory and practice to take place, people's historicity must be the starting point (Freire, 1970). Within the Nunavut context, this includes Inuit Qaujimajatauqangit (Inuit traditional knowledge) and the history of colonization. As Freire explains, a problem-posing approach to education "affirms men and women as beings in the process of becoming - as unfinished, uncompleted beings in and with a likewise unfinished reality" (Freire, 1970, p. 84). Creating a shared narrative, and recognizing that Inuit are in a position to reclaim control of the education system, in partnership with Qallunaat, is a means of fulfilling the promise of education. The successful implementation of change ultimately requires a modification of employees behavior (Gilley et al., 2009). Instead of continuing the trends of lateral violence and hegemonic power relations, both Inuit and Qallunaat need to work in solidarity by accepting and reflecting themselves within the common narrative of colonialism. It is only though this shared narrative that educators can foster a unified commitment to improving the education system.

The Government of Nunavut is currently coping with a severe lack of capacity (Auditor General of Canada, 2010). As such, reform often takes place on a small scale and is often reactive rather than proactive. The need for strong leadership and a committed workforce starts with creating a shared sense of purpose. Establishing a shared narrative of how the history of colonialism continues to shape education in Nunavut through intergenerational trauma and hegemonic relationships is the starting point for change. From here, it will require an understanding that change is a process that must be fought for with consistently and commitment.

\section{Conclusion}

There is a clear tension within the education system in Nunavut. Education can create a path towards reconciling past historical trauma, but it is currently maintaining the status quo. This is because of the failure to provide young people with the necessary tools so that they may be empowered, and in turn, become agents for change within the existing power structure. The ongoing destructiveness of colonialist policies continues through the ongoing intergenerational trauma experienced in Nunavut communities. For this cycle to be broken, society as a whole needs to recognize, understand, and respond to the continued impact of intergenerational trauma on the cognitive, emotional and psychological development of young people (Haskell \& Randall, 2009). For teachers working in Nunavut, living inside these issues is unofficially part of the job description. However, too often schools lack the capacity to deal with such challenging issues on a daily basis, and simply move from crisis-to-crisis. A more systematic approach is required to deal with these issues in order to fulfill the promise of a better future. The development of a discourse around intergenerational trauma is a step in the right direction. As Freire reminds us, "Only dialogue, which requires critical thinking, is ... capable of generating critical thinking. Without dialogue there is no communication, and 
without communication there can be no true education" (Freire, 1970, p. 93).

The development of partnerships between Inuit and Qallunaat, the school and the community, and students and teachers, combined with visionary and inspired leadership, are all integral aspects of the reconciliation process. This is crucial if Nunavummiut are committed to "[f]ulfilling the promise ... [of]... preparing successive generations to participate fully in their own communities and to assume their place as Aboriginal citizens and peoples in global society." (Castellano et al., 2000, p. 255) The failure of education to facilitate civic participation continues to perpetuate dependency and internalized colonialism by keeping students in a state of "permanent present lacking any organic relation to the public past of the times they live in" (Osborne, 2003, p. 605). Education must empower Inuit youth to feel they have a constructive role in the future of their communities. Education can provide a space for healing and public discourse to bring these issues into the public consciousness. For education to fulfill this goal, schools need to develop the necessary awareness and skills to deal with these issues in partnership alongside the communities they serve. Together, through a shared narrative, we can better assist Inuit youth to become empowered by education, and actively participate in the restoration of Inuit Nunangat. (McKechnie, 2014)

\section{References}

Auditor General of Canada (2010). Human Resource Capacity - Government of Nunavut. Retrieved May 23, 2013 from http://www.oagbvg.gc.ca/internet/English/nun_201003_e_33568.html

Aylward, M.L. (2009). Culturally relevant schooling in Nunavut: Views of secondary school educators. Études/Inuit/Studies, 33(1-2), 77-93. http://dx.doi.org/10.7202/044961ar

Barnes, R., Josefowitz, N., \& Cole, E. (2007). Residential Schools: Impact on Aboriginal Students' Academic and Cognitive Development. Canadian Journal of School Psychology, 21(1/2), 18-32.

Battiste, M. (1998). Enabling the autumn seed: Toward a decolonized approach to aboriginal knowledge, language and education. Canadian Journal of Native Education, 22(1), 16-27.

Berger, P. (2007). Some Thoughts on Qallunaat Teacher Caring in Nunavut. Journal of Teaching and Learning, 4(2), $1-12$.

Bombay, A., Matheson, K., \& Anisman, H. (2009). Intergenerational Trauma: Convergence of Multiple Processes among First Nations peoples in Canada. National Aboriginal Health Organization, November, 6-47.

Bradfield, B. (2011). The Dissociation of Lived Experience: A Relational Psychoanalytical Analysis of The Intergenerational Transmission of Trauma. The International Association for Psychoanalytical Self Psychology, 6, 531-550. http://dx.doi.org/10.1080/15551024.2011.606953

Briggs, J. (1998). Inuit Morality Play: The Emotional Education of a Three-Year Old. St John's, NL: Institute of Social and Economic Research.

Brody, H. (2000). The Other Side of Eden. Vancouver: Douglas \& McIntyre.

Calliou, S. (2001). Decolonizing the Mind: A Nonempirical Reflection on First Nations Scholarship. In K.P. Binda and S. Calliou (eds.), Aboriginal Education in Canada: A study in Decolonization (p.195-210). Mississauga: Canadian Educators' Press.

Canadian Red Cross. (2013). Walking the Prevention Circle. Retrieved May 23, 2013 from $\mathrm{http}: / /$ www.redcross.ca/article.asp?id=22276\&tid=030

Castello, M., Davis, L., \& Lahache L. (2000). Aboriginal Education: Fulfilling the Promise. Vancouver: UBC Press.

Dawson, S. (March 11, 2013). MLAs continue to press Aariak on social promotion: "How can you promote kids when they don't have the ability?". Nunatsiaq online. Retrieved March 14, 2013 from

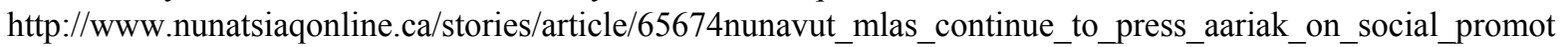
ion1/

Dawson, S. (March 7, 2013). Nunavut MLAs questions social promotion of students in GN schools: "It is doing a great disservice to the youth of Nunavut". Nunatsiaq online. Retrieved March 14, 2013 from http://www.nunatsiaqonline.ca/stories/article/65674nunavut_mla_questions_social_promotion_of_students/

Denham, A. (2008). Rethinking Historical Trauma: Narratives of Resilience. Transcultural Psychiatry, 45(3), 391-414. http://dx.doi.org/10.1177/1363461508094673

Freire, P. (1970). Pedagogy of the oppressed. New York: Continuum. 
Friesen, J., \& Friesen, V. (2002). Aboriginal Education in Canada: A Plea for Integration. Calgary: Detselig Enterprises, Ltd.

Fullan, M., \& Miles, M. (1992). Getting Reform Right: What works and What Doesn't. Phi Delta Kappa International, 73(10), 744-752.

Gilley, A., McMillan, H., \& Gilley, J. (2009). Organizational Change and Characters of Leadership Effectiveness. Journal of Leadership \& Organizational Studies, 16(1), 38-47. http://dx.doi.org/10.1177/1548051809334191

Government of Nunavut (2014). Building Nunavut Together (Sivumut Abluqta). Retrieved September 6, 2014 from http://www.gov.nu.ca/information/sivumut-abluqta

Government of Nunavut, Government of Northwest Territories, Legacy of Hope Foundation. The Residential School System in Canada: Understanding the Past-Seeking Reconciliation - Building Hope for Tomorrow. 2012.

Government of Nunavut. Inuit Qaujimajatuqangit - Guiding Principles. Retrieved on March 2, 2013 from: http://www.gov.nu.ca/files/IQ_Principles_2010.pdf

Haskell, L., \& Randall, M. (2009). Disrupted Attachments: A Social Context Complex Trauma Framework and the Lives of Aboriginal Peoples in Canada. National Aboriginal Health Organization, November, 48-99.

Henderson, A. (2007). Nunavut: Rethinking Political Culture. Vancouver: UBC Press.

Karen, R. (1994). Becoming Attached: First Relationship and How They Shape Our Capacity to Love. New York: Oxford University Press.

Legacy of Hope: An Agenda for Change, Volume 1, Final Report from the Commission of First Nations and Métis Peoples and Justice reform, Chapter 3, "Violence and Victimization," (2004), p.3-2 \& 3-3. Retrieved October 4, 2012 from http://www.justice.gov.sk.ca/justicereform/volumeone/08ChapterThree.pdf

Levesque, S. (2010). On Historical literacy: Learning to think like historians. Canadian Issues, (winter 2010), 42-46.

Lewington, J. (2013). The new face of Aboriginal Education: At rainbow DSB, everyone is learning about First Nation, Métis and Inuit culture - students, teachers and parents. Professionally Speaking, The Magazine of the Ontario College of Teachers, (March), 35-39.

McGregor, H. (2010). Inuit Education and Schools in the Eastern Arctic. Vancouver: UBC Press.

McKechnie, J. (2014). Reconciling the Role of a Qallunaat Teacher in Nunavut. Radical Pedagogy, 11(2), 60-79.

Nunatsaiq News Residential schools secretariat launches call for Group IAP proposals. Retrieved October 9, 2014 from

http://www.nunatsiaqonline.ca/stories/article/65674residential_schools_secretariat_launches_call_for_group_ia p_proposals/

Osborne, B. (2001). Landscapes, memory, monuments, and commemoration: putting identity in its place. Canadian Ethnic Studies, 33(3), 39-79.

Osborne, K. (2003). Teaching history in schools: A Canadian Debate. Journal of Curriculum Studies, 35(5), 585-626. http://dx.doi.org/10.1080/0022027032000063544

Schissel, B., \& Wotherspoon, T. (2003). The Legacy of School for Aboriginal People: Education, Oppression, and Emancipation. Toronto: Oxford University Press.

St. Denis, V. (2007). Aboriginal education and anti-racist education: building alliances across cultural and racial identities. Canadian Journal of Education, 30(4), 1068-1092. http://dx.doi.org/10.2307/20466679

Taylor, C. (1991). The Malaise of Modernity. Concord, Ontario: Anansi Press Limited.

Tester, F., \& Kulchyski, P. (1994). Tammarnitt (Mistakes): Inuit Relocation in the Eastern Arctic, 1939-63. Vancouver: UBC Press.

Tupper, J., \& Cappello, M. (2012). (Re)creating citizenship: Saskatchewan high school students' understanding of the 'good' citizen. Journal of Curriculum Studies, 44(1), 37-59. http://dx.doi.org/10.1080/00220272.2011.618951

Walker, J., Armenakis, A., \& Bernerth, J. (2007). Factors influencing organizational change efforts: An integrative investigation of change content, context, process and individual differences. Journal of Organizational Change Management, 20(6), 761-773. http://dx.doi.org/10.1108/09534810710831000

White, G. (2009). Governance in Nunavut: Capacity vs. Culture? Journal of Canadian Studies, 42(2), 57-81. 
(2012, Oct 25). Automatic passing is failing students say Nunavut DEAs. CBC News. Retrieved of October 26,2012 from: http:/www.cbc.ca/news/canada/north/story/2012/10/25/north-nunavut-autopass.html

(2014, Oct 9) Residential schools secretariat launches call for Group IAP proposals. Nunatsiaq News. Retrieved October

11 , 2014

from

http://www.nunatsiaqonline.ca/stories/article/65674residential_schools_secretariat_launches_call_for_group_ia p_proposals/ 